Original Article

\title{
THE SPECTRUM OF OPPORTUNISTIC INFECTIONS AND ASSOCIATED FACTORS AMONG PEOPLE LIVING WITH HIV/AIDS ON HIGHLY ACTIVE ANTI-RETROVIRAL THERAPY AT MERPATI CLINIC, BALI, INDONESIA: A RETROSPECTIVE STUDY
}

\author{
NOVIANA JOENPUTRI ${ }^{1}$, KETUT SURYANA ${ }^{2}$ \\ 1,2Department of Internal Medicine, Wangaya HIV Study Group, Merpati Clinic, Wangaya General Hospital in Denpasar, Bali, Indonesia \\ Email: noviana.joenputri@gmail.com
}

Received: 30 Mar 2020, Revised and Accepted: 30 Apr 2020

\begin{abstract}
Objective: Infections contributed to higher morbidity and mortality in people living with HIV/AIDS (PLWHA) in both developed and developing countries. This study aimed to describe the spectrum of opportunistic infections (OIs) and associated factors among PLWHA on highly active antiretroviral therapy (HAART) at Merpati Clinic, Wangaya Regional General Hospital in Denpasar, Bali.

Methods: This was a retrospective study. All of PLWHA, who still receiving HAART at Merpati Clinic from January 2018 to January 2020 , who met inclusion and exclusion criteria, were included as subjects in this study. All data were collected through a review of the complete medical record of patients.

Results: The prevalence of OIs in this study was $43.4 \%$. Most PLWHA who experienced OIs were male (68.8\%), age $\leq 40 \mathrm{y}$ old with a median of age $36 \mathrm{y}$ old, educational status senior high school (57.7\%), married (62.1\%), employed (89.7\%), CD4 cell count $\geq 200$ cells/ $\mu \mathrm{l}(67.6 \%)$ and transmission route of HIV non-Intravenous (IV) drug user (99.2\%). Sex, age, marital status, and CD4 cell count were significantly associated with OIs, $\mathrm{p}=0.000, \mathrm{p}=0.005, \mathrm{p}=0.005$, and $\mathrm{p}=0.000$, respectively.
\end{abstract}

Conclusion: The commonest OI in this study was pulmonary tuberculosis. The presence of OIs was associated with sex, age of HIV diagnosis, marital status, and CD4 cell count. With the knowledge of OIs spectrum, clinicians are expected to be able to prevent, diagnose and treat OIs promptly to decrease the morbidity and mortality caused by OIs efficiently.

Keywords: HIV/AIDS, Opportunistic infection, Comorbidities

(C) 2020 The Authors. Published by Innovare Academic Sciences Pvt Ltd. This is an open access article under the CC BY license (http://creativecommons.org/licenses/by/4.0/) DOI: http://dx.doi.org/10.22159/ijpps.2020v12i6.37682. Journal homepage: https://innovareacademics.in/journals/index.php/ijpps

\section{INTRODUCTION}

HIV/AIDS is still a global public health problem [1]. To increase the survival of PLWHA, access to HIV prevention, diagnosis, treatment, or OIs must be improved. OIs are infections that appear more frequently or more severe in immunocompromised people than in immunocompetent people. Although in the HAART era survival of PLWHA is prolonged, this is a challenge for clinicians in managing OIs that arise during the life of patients. Because of the immunosuppression experienced by PLWHA as a natural course of the disease, it can lead patients into life-threatening OIs [2]. Infections contributed to higher morbidity and mortality in PLWHA in both developed and developing countries [3-10]. CD4 cell count has been widely reported as a factor associated with the emergence of OIs $[2,11,12]$.

Studies assessing socioeconomic factors related to the occurrence of OIs are still lacking. There were few studies that described the spectrum of opportunistic infections and associated factors in PLWHA in Bali. This study aims to describe the spectrum of opportunistic infections and associated factors among PLWHA on HAART at Wangaya Regional General Hospital in Denpasar, Bali, Indonesia.

\section{MATERIALS AND METHODS}

\section{Research design}

This retrospective study was conducted from January 2019 to January 2020 at Merpati Clinic, Wangaya Regional General Hospital in Denpasar, Bali, Indonesia. There were 253 patients who participated in this study. Ethical clearance was obtained No: 09/RSUDW/litbang/2019 by Ethical Committee of Wangaya Regional General Hospital in Denpasar Bali.

\section{Population and subjects of the study}

All of PLWHA, who still receiving HAART at Merpati Clinic from January 2018 to January 2020 who met inclusion and exclusion criteria were included as subjects in this study. Inclusion criteria including age more than $17 \mathrm{y}$ old, experienced opportunistic infection during HIV infection, and had a complete medical record. Subjects were excluded if the medical record was not complete. We used a consecutive sampling technique to get the subjects.

\section{Variables and data sources}

All of the data were collected through a review of the complete medical record of patients. Study variables including demographic and socioeconomic data such as sex, age, educational status, marital status, occupation, transmission route of HIV, CD4 cell count, and the presence of OIs.

\section{Statistical analysis}

All the data was processed in the Microsoft excel datasheet. Univariate and bivariate analysis was done using IBM SPSS version 26.0 (IBM SPSS Inc) statistical software. Bivariate analysis was conducted using the Chi-square test. P-value of less than 0.05 was considered statistically significant for all tests.

\section{RESULTS}

Of the total 584 medical records analyzed, 253 (43.4\%) patients experienced OIs. Most PLWHA with OIs were male (68.8\%), aged $\leq 40$ y $(66.0 \%)$ with a median age of $36 \mathrm{y}$, senior high school (57.7\%), married (62.1\%), having a job (89.7\%), CD4 cell count $\geq 200$ cells/ $\mu \mathrm{l}$ (67.6\%), and non-IV drug users (99.2\%). Complete demography and socioeconomic data can be seen in table 1 . 
Table 1: Demographic and socioeconomic data of PLWHA on HAART with OIs

\begin{tabular}{|c|c|}
\hline Variables & n (\%) \\
\hline Total & $253(100)$ \\
\hline \multicolumn{2}{|l|}{ Sex } \\
\hline - Male & $174(68.8)$ \\
\hline - Female & $79(31.2)$ \\
\hline Median of age (years) & 36.0 \\
\hline \multicolumn{2}{|l|}{ Age of HIV diagnosis (years) } \\
\hline - $\quad \leq 40$ & $167(66.0)$ \\
\hline - $\quad>40$ & $86(34.0)$ \\
\hline \multicolumn{2}{|l|}{ Educational status } \\
\hline - $\quad$ Elementary school & $22(8.7)$ \\
\hline - Junior high school & $46(18.2)$ \\
\hline - Senior high school & $146(57.7)$ \\
\hline - Academy/University & $39(15.4)$ \\
\hline \multicolumn{2}{|l|}{ Marital status } \\
\hline - Single & 60 (23.7) \\
\hline - $\quad$ Married & $157(62.1)$ \\
\hline - $\quad$ Divorced or widowed & $36(14.2)$ \\
\hline \multicolumn{2}{|l|}{ Occupation } \\
\hline - Yes & $227(89.7)$ \\
\hline - No & $26(10.3)$ \\
\hline \multicolumn{2}{|l|}{ CD4 cell count (cells $/ \mu \mathrm{l})$} \\
\hline - $\quad<200$ & $82(32.4)$ \\
\hline$\geq 200$ & $171(67.6)$ \\
\hline \multicolumn{2}{|l|}{ Transmission routes of HIV } \\
\hline - IV drug user & $2(0.8)$ \\
\hline Non-IV drug user & $251(99.2)$ \\
\hline
\end{tabular}

IV: intravenous

The three most common OIs were pulmonary tuberculosis (47.8\%), followed by oral candidiasis (43.9\%), and toxoplasmosis (10.3\%). The distribution of OIs can be seen in table 2 .

Table 2: The distribution of OIs among PLWHA on HAART

\begin{tabular}{lll}
\hline Variable & Yes n (\%) & No n (\%) \\
\hline Pulmonary tuberculosis & $121(47.8)$ & $132(52.2)$ \\
Oral candidiasis & $111(43.9)$ & $142(56.1)$ \\
Toxoplasmosis & $26(10.3)$ & $227(89.7)$ \\
Community-acquired pneumonia & $18(7.1)$ & $235(92.9)$ \\
Pneumocystis pneumonia & $11(4.3)$ & $242(95.7)$ \\
Herpes zoster & $11(4.3)$ & $242(95.7)$ \\
Dermatitis seborrheic & $5(2.0)$ & $248(98.0)$ \\
Retinitis cytomegalovirus & $3(1.2)$ & $250(98.8)$ \\
Tuberculosis lymphadenitis & $2(0.7)$ & $251(99.3)$ \\
\hline
\end{tabular}

Patients also experienced comorbidities other than OIs such as hepatitis B (2.4\%) and hepatitis C (0.3\%) coinfection, sexually transmitted disease (STD) (7.1\%), diabetes mellitus (DM) (1.2\%), and hypertension (6.7\%). (table 3) Among PLWHA with DM, all patients had pulmonary tuberculosis as OI.

Table 3: The distribution of other comorbidities among PLWHA on HAART

\begin{tabular}{lll}
\hline Variable & Yes n (\%) & No n (\%) \\
\hline Sexually transmitted disease & $18(7.1)$ & $235(92.9)$ \\
Hepatitis B & $6(2.4)$ & $247(97.6)$ \\
Hepatitis C & $1(0.3)$ & $252(99.7)$ \\
Diabetes mellitus & $3(1.2)$ & $250(98.8)$ \\
Hypertension & $17(6.7)$ & $236(93.3)$ \\
\hline
\end{tabular}

Factors that significantly associated with the occurrence of OIs were sex, age of diagnosis, marital status, and CD4 cells count, $\mathrm{P}<0.05$. Whereas, factors such as educational status, occupation, and transmission routes of HIV were not significantly associated with OIs, p $>0.05$. (table 4.)

Table 4: Factors associated with the occurrence of OIs among PLWHA on HAART

\begin{tabular}{|c|c|c|c|}
\hline Variables & OIs & no-OIs & p-value \\
\hline Total & $253(43.3)$ & $331(56.7)$ & \\
\hline \multicolumn{4}{|l|}{ Sex } \\
\hline - Male & $174(52.3)$ & $159(47.7)$ & $0.000^{*}$ \\
\hline - Female & $79(31.5)$ & $172(68.5)$ & \\
\hline Median of age (years) & 36.0 & 32.0 & \\
\hline \multicolumn{4}{|c|}{ Age of HIV diagnosis (years) } \\
\hline - $\quad \leq 40$ & 167 (39.8) & $253(60.2)$ & $0.005^{*}$ \\
\hline - $>40$ & $86(52.4)$ & $78(47.6)$ & \\
\hline \multicolumn{4}{|l|}{ Educational status } \\
\hline - Elementary school & $22(44.9)$ & $27(55.1)$ & 0.514 \\
\hline - Junior high school & $46(45.1)$ & $56(54.9)$ & \\
\hline
\end{tabular}




\begin{tabular}{|c|c|c|c|}
\hline - $\quad$ Senior high school & $146(41.1)$ & 209 (58.9) & \\
\hline - Academy/University & $39(50.0)$ & $39(50.0)$ & \\
\hline \multicolumn{4}{|l|}{ Marital status } \\
\hline - $\quad$ Single & $60(52.6)$ & $54(47.4)$ & $0.005^{*}$ \\
\hline - $\quad$ Married & $157(38.9)$ & $247(61.1)$ & \\
\hline - Divorced or widowed & $36(54.5)$ & $30(45.5)$ & \\
\hline \multicolumn{4}{|l|}{ Occupation } \\
\hline - Yes & $227(43.4)$ & $296(56.6)$ & 0.907 \\
\hline - $\quad$ No & $26(42.6)$ & $35(57.4)$ & \\
\hline \multicolumn{4}{|l|}{ CD4 cell count (cells/ $\mu \mathrm{l})$} \\
\hline - $\quad<200$ & $82(58.6)$ & $58(41.4)$ & $0.000^{*}$ \\
\hline - $\quad \geq 200$ & $171(38.5)$ & $273(61.5)$ & \\
\hline \multicolumn{4}{|l|}{ Transmission routes of HIV } \\
\hline - IV drug user & $2(66.7)$ & $1(33.3)$ & 0.413 \\
\hline - $\quad$ Non-IV drug user & $251(43.2)$ & $330(56.8)$ & \\
\hline
\end{tabular}

IV: intravenous; ${ }^{*} \mathrm{p}<0.05$ was statistically significance

\section{DISCUSSION}

The overall prevalence of OIs in this study was $43.3 \%(n=253 / 584)$. This was similar to Study Alemayehu et al. in Ethiopia (45.3\%) [13]. Most PLWHA who experienced OIs were male and age $\leq 40$ y old (66.0\%). These findings were similar with the previous study, which reported male PLWHA experienced more OIs than females with age 29-35 group [14]. But, male to female ratio in this study seems lower than a similar study in India, 2.2:1 vs 3.09:1, respectively [14]. The median of age in this study was $36 \mathrm{y}$ old, it is similar to previous studies [15-17].

Pulmonary tuberculosis (47.8\%) followed by oral candidiasis $(43.9 \%)$, and toxoplasmosis $(10.3 \%)$ were the most frequently observed OIs. Previous studies also reported the most prevalent OIs were pulmonary tuberculosis followed by oral candidiasis [2, 12, 1721]. Oral candidiasis was previously reported as the most prevalent OI fungal in PLWHA due to severe suppression of the immune system [22].

One of the important complications in PLWHA patients treated by HAART is the immune reconstitution inflammatory syndrome (IRIS) phenomenon $[23,24]$. Around $30 \%$ of PLWHA with tuberculosis coinfection have a risk of tuberculosis-associated IRIS (TB-IRIS) [25]. TB-IRIS can appear as paradoxical tuberculosis or unmasking tuberculosis-associated IRIS [26]. A study reported patients with TBIRIS had characteristics such as a mean of age $35.87( \pm 8.54)$ years, a mean of CD4 cell count $200( \pm 263)$, a form of tuberculosis lymphadenitis $(75 \%)$, and IRIS mostly occurred about $1-4 \mathrm{w}$ after HAART initiation [27]. In this study, there were no patients who met the paradoxical or unmasking tuberculosis-associated IRIS criteria.

The prevalence of pneumocystis pneumonia (PCP) in this study was $4.3 \%$, it was lower than reported by Kumar et al. [18]. It may be caused by the lack of facilities for PCP diagnosis in our hospital. The prevalence of herpes zoster in this study also lower from the previous study, $4.3 \%$ vs $11.2 \%$, respectively [15].

Patients also experienced comorbidities other than OIs such as hepatitis B (2.4\%) and hepatitis C $(0.3 \%)$ coinfection, STD (7.1\%), diabetes mellitus (1.2\%), and hypertension (6.7\%). (table 3) STD in this study was more prevalent than reported by Bhaumik et al. [16]. It might be caused by most HIV transmission routes in this study was non-IV drug users or sexually. HIV/AIDS and DM are known as the disease that suppressed cell-mediated immunity, thus causing patients more susceptible to OIs. Among PLWHA with DM in this study, all the patients had pulmonary tuberculosis as OI. Indira et al. reported, there was no profile difference of OIs between PLWHA with or without DM [28].

Factors that significantly associated with the occurrence of OIs in this study were sex $(\mathrm{p}=0.000)$, age $(\mathrm{p}=0.005)$, marital status $(\mathrm{p}=0.005)$, and CD4 cell count $(\mathrm{p}=0.000)$. Iroezidu et al. also reported that age and CD4 cell count were significantly associated with OIs but not with sex and marital status [29]. Patients with age $\leq 40$ y old experienced OIs 1.89 times higher $(\mathrm{p}=0.02)$ [29]. Some similar studies reported that CD4 cell count significantly associated with the occurrence of OIs $[2,11,12]$. The risk of OIs was significantly higher in patients with current $\mathrm{CD} 4$ cell count $<200$ cells $/ \mu \mathrm{l}(\mathrm{OR}=6.11,95 \%$ $\mathrm{CI}=3.46-10.78, \mathrm{p}<0.0001)$ [29].

Fungal OIs that most commonly appeared on CD4 cell count $<200$ cells/ $\mu \mathrm{l}$ were oral candidiasis, cryptococcal meningitis, and PCP [22]. Patients with $\mathrm{CD} 4$ cell count $<200$ cells $/ \mu \mathrm{l}$ had higher risk to pulmonary tuberculosis $(9.4$ times, $\mathrm{p}<0.001)$, oral candidiasis $(27.2$ times, $\mathrm{p}<0.001$ ), and pneumonia ( 11.1 times, $\mathrm{p}=0.008$ ) [2]. OIs that most commonly appeared on CD4 cell count $>200$ cells/ $\mu$ l were tuberculosis and candidiasis [14]. This may cause the most OIs in this study were pulmonary tuberculosis and oral candidiasis. Therefore, patients with CD4 cell count $<200$ cells $/ \mu \mathrm{l}(32.4 \%)$ in this study need more attention to the occurrence of life-threatening OIs.

The strengths of this study are a large number of samples and most of the medical record data are complete. The lack of several diagnostic support for OIs in PLWHA become the limitation of this study. It might cause some OIs to be undiagnosed.

\section{CONCLUSION}

Although all of the patients have received HAART, the prevalence of OIs is still high. The commonest OIs in this study were pulmonary tuberculosis, followed by oral candidiasis and toxoplasmosis. The presence of OIs was associated with sex, age of HIV diagnosis, marital status, and CD4 cell count. There were no patients occurred with IRIS. With the knowledge of the OIs spectrum, clinicians are expected to be able to give more education to PLWHA on HAART about personal hygiene and medication compliance. Regular and systematic medical examination, early diagnosis, and prompt treatment of OIs are needed to decrease the morbidity and mortality caused by OIs efficiently.

\section{ACKNOWLEDGMENT}

We would like to thank all colleagues in Wangaya HIV Study Group at Merpati Clinic for the support in this project.

\section{FUNDING}

This research received no specific grant from any funding agency in the public, commercial, or not-for-profit sectors.

\section{AUTHORS CONTRIBUTIONS}

All authors contributed to the concept of study. All authors also had full access to the data, contributed to the study, approved the final version for publication, and take responsibility for its accuracy and integrity.

\section{CONFLICTS OF INTERESTS}

All authors have disclosed no conflicts of interest.

\section{REFERENCES}

1. WHO HIV/AIDS Fact Sheet. Available from: https://www.who.int/news-room/fact-sheets/detail/hiv-aids [Last accessed on 10 Mar 2020]

2. Damtie D, Yismaw G, Woldeyohannes D, Anagaw B. Common opportunistic infections and their CD4 cell correlates among 
HIV-infected patients attending at antiretroviral therapy clinic of Gondar University Hospital, Northwest Ethiopia. BMC Res Notes 2013;6:534.

3. Seage GR, Losina E, Goldie SJ, Paltiel AD, Kimmel AD, Freedberg KA. The relationship of preventable opportunistic infections, HIV-1 RNA, and CD4 cell counts to chronic mortality. J Acquired Immune Defic Syndr 2002;30:421-8.

4. Gebo KA, Fleishman JA, Moore RD. Hospitalizations for metabolic conditions, opportunistic infections, and injection drug use among HIV patients: trends between 1996 and 2000 in 12 states. J Acquired Immune Defic Syndr 2005;40:609-16.

5. Buchacz K, Baker RK, Moorman AC, Richardson JT, Wood KC, Holmberg SD, et al. HIV outpatient study (HOPS) investigators. Rates of hospitalizations and associated diagnoses in a large multisite cohort of HIV patients in the United States, 19942005. AIDS 2008;22:1345-54.

6. Bonnet F, Chene G, Thiebaut R, Dupon M, Lawson Ayayi S, Pellegrin JL, et al. Groupe d'Epidemiologie clinique du SIDA en aquitaine (GECSA). Trends and determinants of severe morbidity in HIV-infected patients: the ANRS CO3 aquitaine cohort, 2000-2004. HIV Med 2007;8:547-54.

7. Palella Jr FJ, Baker RK, Moorman AC, Chmiel JS, Wood KC, Brooks JT, et al. HIV Outpatient study investigators mortality in the highly active antiretroviral therapy era: changing causes of death and disease in the HIV outpatient study. J Acquired Immune Defic Syndr 2006;43:27-34.

8. Cascade Collaboration. Effective therapy has altered the spectrum of cause-specific mortality following HIV seroconversion. AIDS 2006;20:741-9.

9. Hooshyar D, Hanson DL, Wolfe M, Selik RM, Buskin SE, McNaghten AD. Trends in perimortal conditions and mortality rates among HIV-infected patients. AIDS 2007;21:2093-100.

10. Lewden C, May T, Rosenthal E, Burty C, Bonnet F, Costagliola D, et al. Changes in causes of death among adults infected by HIV between 2000 and 2005: The "Mortalite 2000 and 2005" surveys (ANRS EN19 and Mortavic). J Acquired Immune Defic Syndr 2008;48:590-8.

11. Solomon FB, Angore BN, Koyra HC, Tufa EG, Berheto TM, Admasu M. Spectrum of opportunistic infections and associated factors among people living with HIV/AIDS in the era of highly active antiretroviral treatment in dawro zone hospital: a retrospective study. BMC Res Notes 2018;11:604.

12. Khanal VK, Jha N, Karki P, Paudel IS. Opportunistic infections and clinical profile of HIV/AIDS patients: a study from eastern region of Nepal. Nepal Med Coll J 2014;16:194-7.

13. Alemayehu M, Yisehak Y, Alaro W, Alemayehu B. Opportunistic infections among HIV/AIDS patients taking ante-retroviral therapy at tertiary care hospital in Wolaita zone, southern Ethiopia. J AIDS Clin Res 2017;8:2.

14. Halgarkar CS, Nilekar SL. HIV prevalence and the co-relation of different opportunistic infections with CD4 cell count. Indian Medical GAZETTE; 2014.p. 157-60.
15. Mitiku H, Weldegebreal F, Teklemariam Z. Magnitude of opportunistic infections and associated factors in HIV-infected adults on antiretroviral therapy in eastern Ethiopia. HIV/AIDS (Auckl) 2015;7:137-44.

16. Bhaumik P, Debnath K, Sinha B. Spectrum of opportunistic infections among HIV/AIDS patients of Tripura. J Indian Acad Clin Med 2013;14:218-21.

17. BS Chavan, VR MR, Arshad M, Sayana SB. Factors influencing the substitution of art in HIV/AIDS patients on first line highly active antiretroviral therapy. Asian J Pharm Clin Res 2014;7:117-20.

18. Kumar R, Bishnoi BR. Opportunistic infections among HIV patients attending tertiary care hospital, Bikaner, Northern Western Rajasthan, India. Int J Med 2018;4:58-61.

19. Sharma SK, Kadhiravan T, Banga A, Goyal T, Bhatia I, Saha PK. Spectrum of clinical disease in a series of 135 hospitalized HIVinfected patients from north India. BMC Infect Dis 2004;4:52.

20. Kumawat S, Kochar A, Sirohi P, Garhwal J. Socio-demographic and clinical profile of HIV/AIDS patients on HAART era at a tertiary care hospital in North-West Rajasthan, India. Int J Community Med Public Health 2016;3:2088-93.

21. Insaniputri P, Supardi S, Andrajati R. Comparison of zidovudine combination and tenofovir combination on the effectiveness of therapy and side effects in hiv/aids patients in rsal mintohardjo. Asian J Pharm Clin Res 2017;10:93-6.

22. Jain S, Singh AK, Singh RP, Bajaj JK, Damle AS. Spectrum of opportunistic fungal infections in HIV-infected patients and their correlation with CD4+counts in western India. J Med Microbiol Infectious Disease 2014;2:19-22.

23. Shelburne SA, Hamill RJ. The immune reconstitution inflammatory syndrome. AIDS Rev 2003;5:67-79.

24. French MA, Price $P$, Stone SF. Immune restoration disease after antiretroviral therapy. AIDS 2004;18:1615-27.

25. Lawn SD, Bekker LG, Miller RF. Immune reconstitution disease associated with mycobacterial infections in HIV-infected individuals receiving antiretrovirals. Lancet Infect Dis 2005;5:361-73.

26. Meintjes G, Lawn SD, Scano F, Maartens G, French MA, Worodria W, et al. Tuberculosis-associated immune reconstitution inflammatory syndrome: case definitions for use in resource-limited settings. Lancet Infect Dis 2008;8:516-23.

27. A PK, GP, Sn M, Ap S, Swamy V, Rama S. Clinical outcomes of use of hydroxychloroquine in paradoxical tuberculosis-immune reconstitution inflammatory syndrome in HIV-infected patients. Asian J Pharm Clin Res 2018;11:439-41.

28. Indira $\mathrm{P}$, Kumar $\mathrm{PM}$, Shalini $\mathrm{S}$, Vaman K. Opportunistic infections among people living with HIV (PLHIV) with diabetes mellitus (DM) attending a tertiary care hospital in coastal city of South India. PloS One 2015;10:e0136280.

29. Iroezindu MO, Ofondu EO, Hausler H, Van Wyk B. Prevalence and risk factors for opportunistic infections in HIV patients receiving antiretroviral therapy in a resource-limited setting in Nigeria. J AIDS Clin Res 2013;3:1-9. 